\title{
Traveling with the Picatrix: cultural liminalities of science and magic
}

In his bold De hominis dignitate (On the Dignity of Man), dated 1486, Giovanni Pico della Mirandola claimed that natural magic originated in Persia and India. Zoroaster's magic, Pico continued, was the same divine art conveyed to Persian princes teaching 'how to rule according to the dogma of the world republic'. Toward the end of his oration, Pico discussed the origins of natural magic: Pythagoras, Empedocles, Democritus, and Plato, he explained, had acquired magic's secrets in far-off lands. For them, this Eastern philosophy was the most sublime of all arts. From the Persians it had been conveyed to the Greeks and the Arabs, who transferred it to Renaissance intellectuals (della Mirandola 1998, 29).

In recent years scholars have taken up Pico's invitation and started exploring the chain of transmission from the Arab world to European philosophers and practitioners of natural magic during the Renaissance (Boudet, Caiozzo and Weill-Parot 2011; Saif 2015). Important works focusing on the Picatrix have shed light on the ways it contributed to the formation of a philosophical framework around ideas derived from magic. ${ }^{1}$

Here, however, I would like to probe a complementary perspective and to point out the connection between the multiple receptions of the Picatrix (Ghāyat

1 In the mid-1970s, Vittoria Peronne Compagni forcefully delved into the religious and moral aspects of the Picatrix, showing its great effect on various fields of the intellectual life of the Renaissance (see Perrone Compagni 1975; idem 1977). Eugenio Garin stressed the importance of the text as a link between divinatory astrology and natural magic, stating its role in arguing that 'the celestial powers, in fact, come to be caught, and placated or used, by imprisoning them in fictitious material representations, talismans and amulets, capable of absorbing and concentrating astral forces'. Garin held that the Picatrix was for this process 'as indispensable as the Corpus Hermeticum or the writings of Albumasar for understanding a conspicuous part of the production of the Renaissance, including the figurative arts' (Garin 1983, 47). Paola Zambelli further underscored the importance of the Picatrix to the rise of natural magic, brilliantly showing that the text was read and digested even before the rediscovery of the Corpus Hermeticum (see Zambelli 2007 , 9). Anthony Grafton ingeniously showed that the unacknowledged citation of the Picatrix teaches us about methods of note taking and how knowledge was classified in the Renaissance (see Grafton 2004). More recently Bernd-Christian Otto has insightfully pointed out the crucial role cross-cultural and long term exploration of the history of several canonical works, such as the Picatrix, have had for the progress of our understanding of the origins and role of magic in Western civilisation (Otto 2016). 
al-hakim [literally, 'the purpose of the sage']) $)^{2}$ and the ways in which natural magic challenged the tenets of late medieval philosophy of nature. The implied presence of the work in the writings of three Renaissance philosophers - Marsilio Ficino, Heinrich Cornelius Agrippa, and Tommaso Campanella - appears in connection to their discussion of natural magic, which aimed at revising the principles of natural philosophy by asserting such notions as action at a distance, natural motion by agency, the centrality of the sun, the linear motion of light rays, and the practical role of the individual, the magus, in making philosophy. Such radical physical notions could not appear without the reviving interest in ancient religions and without the rising demand to individualise not only the practices for knowing God but also the practices for knowing nature.

I argue that such assertions indicate the central role the Picatrix played in reviving ancient religious practices for knowing nature and combining them with a contemporary philosophy of nature, pointing out that the origins of natural magic are rooted in ancient eastern religions. Thus, the Picatrix played a central role in, to use the words of Brian Copenhaver, the 'rebirth of natural philosophy that encouraged natural magic by grounding it in eclectic Aristotelian thought' (Copenhaver 2015) and also in providing the impetus towards the first phase of the scientific revolution, as Frances Yates long argued (Yates 1964).

\section{The text}

Picatrix is a talismanic text from eleventh-century Iberia. ${ }^{3}$ Although background information about the text and its author are obscure, Maribel Fierro has attributed the work to a tenth-century Andalusian mathematician named Maslama b. Qāsim al-Qurțubī (Fierro 1996, 105-7). Originally written in Arabic, it was first translated into Hebrew by an unknown translator. Alfonso X, as part of his campaign to turn the Castilian vernacular into an imperial and intellectual language,

2 Since Renaissance scholars read the Picatrix from complete or incomplete manuscript copies of the Latin translation, there was no single fixed text. Therefore, I am using the printed edition prepared by David Pingree (1986), who meticulously compared the extant manuscripts and excerpts that have survived in European archives. To give a complementary view, I have provided the relevant passages from the Arabic edition published by Hellmut Ritter in Leipzig in 1933. At some points the two versions diverge, indicating that the Latin text had a life of its own.

3 Some scholars question whether the text was originally produced in Spain. Godefroid de Callataÿ argues that the text is rooted in the tradition of the Ikhwān al-safā', the great occultist encyclopedia of the Iraqi Brethren of Purity and the Sabeism harrānien, thus stressing that its origins are in the Middle East and not Spain (see Callataÿ 2011). 
ordered its translation into Spanish in 1256 (Pingree 1981, 47; Avilés 2011, 95-123). Christian scholars later produced a Latin version, explaining their choice of title by spinning the following yarn: 'The wise, noble, and honored philosopher Picatrix (perhaps a distortion of Arabic name, perhaps Buqatris [Hypocrates]) compiled it from two hundred different books and many philosophers' ${ }^{4}$ Practitioners of natural magic copied, read, and circulated the text in Europe between approximately 1450 and 1600, incorporating parts of it into the tenets of scholastic philosophy. ${ }^{5}$ By the late fifteenth century and early sixteenth century, several key authors who modelled a universe strung along fields of forces, and who evidently had access either to fragments, or the whole manuscript, of the Picatrix, appropriated such selective approach to offer significant additions to explain exceptional natural phenomena that were ignored by the traditional philosophy of nature.

The author, or Picatrix as the Latin translation named him, divided the work into four books, each containing about a dozen chapters. A glance at the table of contents reveals the scope of the work, which includes philosophical expositions that provided the necessary grounding, according to the author, for anyone interested in learning about natural magic. Among these doctrines one finds a theory of magic, the role of the anima mundi (the soul of the universe) in generating motion, the centrality of the sun in dispersing the anima mundi, and the role of the magician in exposing and controlling such physical-spiritual connections through experimentation and the quantification and manipulation of the forces of nature. However, the text does not merely elaborate on the ways bodies act at a distance through the medium of spiritual-physical entities (forces, radiation, heat). It also furnishes its readers with the practices needed to control such entities, including the manipulation of the influences of the heavenly bodies.

The author explains in his preface that he means to shed light on the nature of magic, a secret closely guarded by ancient philosophers. Here was a turning point, a moment when esoteric and scattered pieces of knowledge concerning natural magic are collected into a kind of 'guide for the perplexed', making natural magic accessible to the public. In addition to the somewhat vague reference to

4 Citation from the prologue of the Latin translation: 'Hoc autem opus perfectum fuit anna Domini MCCLVI, Alexandri MDLXVIII. Cesaris MCCXCV, et Arabum DCLV. Sapiens enim philosophus, nobilis et honoratus Picatrix. hunc librum ex CC libris et pluribus philosophie compilavit, quem suo proprio nomine nominavit' (Magrīịi 1986,1).

5 Nicholas Weill-Parot has argued that scholastics defined the proper use of the Picatrix by stressing that talismans reinforce the traditional similitudo, correspondence of matter and form, emphasising that the components of talismanic images pertain to the natural characteristics of the planets and by so doing rejecting the ceremonial constituents of the Picatrix (Weill-Parot 2011). 
'two hundred books', Picatrix mentions various specific sources of ancient religions, primarily Indian, Chaldean, and Nabatean texts, as well as Greek works and Egyptian accounts concerning Hermes, showing an impressive mastery of ancient Eastern religious cultures, themselves apparently acting at a distance on this Andalusian writer. Conscious of his position in an idiosyncratic historical moment, the author occassionaly stresses that he has been exposed to cultural currents that brought with them pieces of magical knowledge and practices produced with reference to various cultural vantage points, all of which required him to sort them out, standardise them, and collect them into a single book.

The book's principle is stated at the outset: philosophy was crucial for natural magic not as a metaphysical frame of reference but as the practical means of revealing 'the causes of reality', and thus as a guide to manipulating it. The author then defined philosophy of magic as having three substantial characteristics: 'it develops and does not decline, it is an active exploration and not a passive one, it is ready to be exposed and it does not distance itself [from the true seeker]'. The philosophy of magic also has three utilitarian factors: 'it teaches, it educates, and it is not ready to be perceived by those who turn their back to it'. Thus, Picatrix prescribes the conditions for the study and the usage of natural magic: 'whoever desires to explore, ought to acquire a passion for the sciences and thoroughly scrutinise their rules', so as to utilise such knowledge, the secrets of which 'have a great purity with which you will be able to help many' ${ }^{6}$ Natural magic is difficult to understand since it deals with intangible spiritual-physical entities, utilising 'connections hidden from our senses and sight'. After all, the word magic refers 'to all things hidden from the senses'. The Picatrix states,

You should know that magic is by and large everything that enchants the intellect and that the souls are drawn to it. Thus, the wondering, the attraction, and the praising [in magical acts] are expressions of the actual difficulty the intellect has in grasping and understanding it. The causes (forces of nature) are hidden from the ignorant, and it is a divine force that is being expressed [in natural indications], so that the magus would perceive them. Thus, [natural magic] is the science of perception of the hidden causes [of nature].

6 For the Arabic text see Magrīṭi 1933, 5.

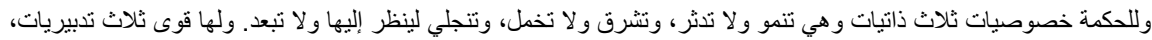

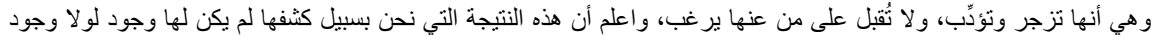

الحكمة.

For the equivalent Latin text: 'Quare scias quod hoc secretum quod in hoc nostro libro intendimus discooperire acquiri non potest nisi prius acquiratur scire. Et qui scire intendit acquirere studere debet in scienciis et eas ordinatim perscrutari quia hoc secretum haberi non potest nisi per sapientem et studentem in seiencia ordinatim. In hoc autem secreto est magna puritas cum qua te multum adiuvare poteris'. Magrītịi 1986, 4. 
Beyond theoretical and linguistic analysis of the notion of magic, the Picatrix draws a connection between the practice of magic and its disciplinary boundaries within magic:

in practice, the subjects of this science are spirit in spirit and this is in the realm of imagination; spirit in substance, this is the realm of talisman; and substance in substance, this is the realm of alchemy. In short, most of the causes of magic are hidden from the intellect and it is difficult to perceive them.

However, by controlling that which the senses cannot detect, natural magic 'violates' the order of things. The original Arabic text stresses that 'the word talisman is actually the inverse writing of the word musalit, to conquer and dominate a substance', and, therefore, a talisman serves as a 'violator': 'whoever makes an image attempts to dominate the destiny of an object by violence'. ${ }^{7}$ The role of the talisman is to violate and manipulate the order of nature, to expose the things hidden from the senses.

The text goes on to integrate the Aristotelian philosophical tradition with the practice of magic, dividing magic into theoretical ('ilmī) and practical ('amalī) knowledge. ${ }^{8}$ The theoretical relates to knowing the positions of the stars and the ways their 'rays project toward the center-earth', propagate through planetary spheres, and generate motion. Practical knowledge, on the other hand, relates to 'the combination of natural qualities with the virtue infused by the fixed stars', particularly elemental heat. ${ }^{9}$ Since the theoretical and the practical are intertwined and mutually conditioned, the art of magic places man in the center, bringing the theoretical down to earthly concerns, and lifting practices up to sublimities.

The seemingly effortless combination of various fields and its essentially unique typology of knowledge gave the text its power of attraction. From Renaissance men such as the Florentine Neo-Platonist philosopher Marsilio Ficino,

7 Magrīịi 1933, book 1, chap. 2, 7.

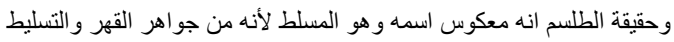

'Et ymagines sapientes appellant telsam, quod interpretatur violator quia quicquid facit ymago per violenciam facit et pro vincendo facit illud pro quo est composita'. Magrịịi 1986, book 1, chap. 2.5. 8 Magrịtī 1933, book 1, chap. 2.8.

إن السحر مقيد في قسمين علمي و عملي

'Et dico quod nigromancia dividitur in duas partes, scilicet in theoricam et Practicam', see Magrīịi 1986, book 1, chap. 2, 6 .

9 Magrịịi 1933, book 1, chap. 2.8-9.

و العملي هو الوقوف على المولدات الثلاثة وما أثبت فيها من قوى الكو اكب السيَارة 'Practica vero est composicio trium naturarum cum virtute infusionis stellarum fixarum', see Magrị̣̂i 1986, book 1, chap. 2.6. 
through natural magicians like Cornelius Agrippa, and up to early modern political utopians such as Campanella, radical thinkers started looking for a bottom-up approach to the philosophy of nature. In mixing an Aristotelian philosophy of nature with natural magic that was rooted in individual religious practices from the ancient East, they provided a unified program for the exploration of nature, which included explanations concerning the natural phenomena of action at a distance. Such Renaissance men identified natural magic not only with ancient Greek philosophy but actually with ancient eastern religious cultures.

The morphological readings of the works of Ficino, Agrippa, and Campanella against the backgound of the Picatrix expose direct citations and excavate latent remnants of the Andalusian grimoire, particularly with respect to four ideas central to the connection between natural magic and early modern science the necessary agency for natural motion; the role of the virtuoso in violating the order of nature, manipulating its laws, and exposing the existence of intangible physical entities, such as forces; the centrality of the sun; and, finally, the linear motion of rays and forces.

\section{Philosophising magic: Ficino's animated cosmos}

In writing one of the most influential works on magic, De vita libri tres (On the Three Books of Life), dated 1489, Marsilio Ficino, a senior colleague of Pico's, relied on several sources. Scholars have pointed at a number of potential sources. His Latin translation of the Greek body of Hermetic lore and al-Kindī's De radiis stellarum have been seen by some as evidence for the permeation of the theory of rays (Saif 2015). Others suggest that the whole section III in De vita was influenced by scholastic sources (Copenhaver 1984, 523f.). A reading of section III in De vita against the Picatrix reveals that Ficino not only used the Picatrix as a source but that it served as a crucial reference for his philosophical framing of astral magic. Ficino applied generic names to the borrowed material, typically labeling it 'Arabian', and sometimes simply reproduced passages from the Picatrix without attribution.

Paula Zambelli has shown that Ficino had his reasons for this strategy. Manuscripts of the Picatrix circulated widely. Indeed, so wide was their circulation amongst those with philosophical interests in Tuscany that the rector of the University of Pisa, Fillipo Valori, asked Ficino to borrow his copy of the text. A student of Ficino, Michele Acciari, replied on his sick teacher's behalf, highlighting the reading and writing strategies of Ficino, who read the Picatrix closely 
despite dismissing major parts of the text as superstitious. He nevertheless incorporated 'whatever in it ... was useful and worth reading, copying it into his own book, De vita libri tres. The rest - whatever he found vain, ineffectual, or contrary to the Christian religion - he omitted'. Acciari writes of the text that 'Ficino himself warns you against reading it, because you will have to labour hard [to understand it] but you will find little of any practical use, especially since whatever is in any way useful or important in that work may be read point for point perhaps better and certainly more fully and clearly in his book De vita libri tres. If you read the latter thoughtfully and carefully you won't miss a thing from the famous Picatrix' ${ }^{10}$ Zambelli has forcefully concluded that Ficino was interested in highlighting his own works, De Vita and the translation of the Corpus hermeticum, at the expense of the Picatrix, despite this source playing a more central role in his writings than he was willing to admit.

Ficino's selective reading of the Picatrix perhaps also resulted from reading partial versions of the text, which were circulated as incomplete manuscripts or as excerpts in a number of folios. David Pingree has pointed out that Ficino drew almost exclusively on books 3 and 4 of the Picatrix, raising the possibility that he read an incomplete manuscript that included only the last two books [3, 4]. Indeed, just such a manuscript is known to have been circulated in his immediate surroundings. ${ }^{11}$

Book 3 of De vita libri tres starts by posing a philosophical problem: if intellect and matter belong to separate spheres, what then creates motion? Is there a philosophical means of 'taming' the magical principle of action at a distance? Ficino addresses this central question by trying to define the agency of natural motion. If the universe were made up only of intellect and body, 'then neither would the intellect be attracted to the body nor would the body be drawn to the intellect'. Agency is required. What permits an 'attraction' between bodies, Ficino implies, is the soul that acts between body and intellect, a carrier of secondary qualities. Agency, in the form of the soul, manifests itself as a spiritual-physical entity. Such a soul, Ficino concludes, has to be universal and ought to be understood as

10 But for all of that enthusiasm, the subject matter appears to have been viewed by others as off limits. When the nephew of 'Giorgio the doctor' (Paola Zambelli has identified the latter as Giorgio Anselmi da Parma the Elder) wished to publish his uncle's treatise on magic, the printers whom he approached steadfastly refused (Zambelli 2007, 9). See also Delcorno Branca 1976, 464-71, esp. 470f.

11 The manuscript is Bodleian Library, Canonicianus classicus latinus 500; see Magrītị 1986, xxii. 
'equally connected with everything, even with those things that are at a distance from one other'. ${ }^{12}$

With this declaration, Ficino framed previous magical or theological attacks on the hegemonic philosophy of nature, not merely in order to topple this philosophy but, rather, to tame practitioners of magic by imposing on them a philosophical framework. This meant harking back to authoritative sources that preceded Aristotle. In contending that 'the cosmos is animate just like any animate thing', Ficino alerts his readers to the fact that he has adopted this from the traditional Neo-Platonist philosophy and from 'Arabic astrologers' who 'thoroughly proved it'. They also proved, he explains, that 'by applying our spirit to the spirit of the cosmos, made possible by physical science, we received celestial goods in our soul and our body'. Just as our bodies need a spirit to function, so the anima mundi is essential to the working of the cosmos, acting 'by way of the rays of the stars upon nature and upon our spirit'. ${ }^{13}$

Ficino's attributions of passages from the Picatrix to 'an Arabic astrologer' or 'Arabic writers' serve to support current magical arguments about the animated cosmos and to justify the principle of action at a distance. Such assertions played an essential role in his effort to draw counters to a new natural philosophy that would not only break with the teleological explanations for motion but would also establish a new structure of the universe. It was the Picatrix that provided him with such a metaphysical framework.

Only the last parts of the Picatrix delve into the theoretical tenets of magic, with the author outlining a philosophical framework for natural magic in the last chapter of book 3. He begins by discussing the confusing usage of 'nature': 'nature' was variously used to refer to the 'complexion of the elements', innate heat, 'forms and figures of the body', and motion and spirit. Aristotelian natural philosophers, Picatrix stresses, used the word even more equivocally, meaning 'the body and all its properties', the humors, 'elements of heaven', and 'Godly virtues that cause generation and corruption'. The initial philosophical challenge taken up in the Picatrix is to sort out the word's true meaning, setting it alongside the magician's fascination with action at a distance. The text stresses that 'The sages have defined "nature" as the beginning of motion and rest' (my emphasis).

12 'Praeterea cum sit (ut dixi) media rerum, omnia suo in se modo continent et utrinque ratione propinquo; ideoque conciliatur et omnibus, etiam aequaliter illis quae inter se distant, ab ea videlicet non distanibus' (Ficino 1989, book 3, chap. 1, 244).

13 'Quem sicut et quodvis animal multoque efficacius animatum esse, non solum Platonicae rationes, sed etiam astrologorum Arabum testimonia comprobant. Ubi etiam probant ex application quadam spiritus nostril ad spiritum mundi per artem physicam affectumque facta, traiici ad animam corpusque nostrum bona coelestia' (Ibid., book 3, chap. 2, 254). 
Such motion is generated through 'the heavenly mediation between forms and bodies', a universal agency. ${ }^{14}$

Book 4 opens by arguing that the seemingly scattered spiritual-physical agents, the forces of life (qūat al-hayāt) that rest in bodies, are actually representations of a single entity, the anima mundi (nafs al-kul). The anima mundi manifests itself as the force that generates motion, as 'a kind of property apart from material things', as spiritual phenomena (ashyā' al-rūḥaniyya), spiritual-physical entities that cause objects to 'move naturally and not by accident'. This property 'governs everything' and exists simultaneously everywhere. ${ }^{15}$

If the anima mundi is the mediating agent that plays between bodies then it has to be located in the midst of the cosmic order. Book 4 of the Picatrix describes the five-tiered structure of the universe, assigning a place to the anima mundi:

1) First form [al-șūrah] (the order of things)

2) Intellect [al-'aql] (laws of causality)

3) Anima [al-nafs] (universal agent)

4) Nature [al-țabīah] (motion and rest)

5) Elements [al-'anāṣir] (mixture of matter) ${ }^{16}$

The particular location of the anima mundi determines its function in the cosmic order. Lodged between the highest and the lowest spheres, the soul of the world plays a mediating role in the universe; as the prime agent of natural change, transforming divine laws into tangible light, it relies on light to set nature into motion. 'When the soul comes into agreement with the mind', Picatrix explains, 'it creates light and wisdom and other virtues'. Perpetually in flux, nature shifts

14 Magrītị 1933, book 3, chap. 12, $284 \mathrm{f}$.

لذلك حدها الأو ائل بأنها ابتذاء حركة وسكون وحدها

'Qua de causa primi sapientes sic diffiniverunt earn quod est terminus et principium motus et quietudinis’. Magrịịi 1986, book 3, chap. 12, 172.

15 Magrīṭi 1933, book 4, chap. 1, 291-92.

هذه الجملة هي العقل الفعَال المخرج للأنفس الإنسانية في العلوم العقلية من القوة إلى الفعل وهذه الجملة هي مبادئ الكل بعد المبدأ

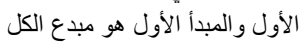

'Et hoc genus est principium in omnibus post primum principium; et principium primum principians omnia'. Magrīịī 1986, book 4, chap. 1, 177.

16 Magrīṭi 1933, book 4, chap. 1, 291f.

و هي العالم الأعلى والصورة الاولى وهو العنصر الأول ثم العقل ثم النفس ثم الطبيعة وهي السماء ثم العنصر الجرمي وهو العنصر

'Sapientes vero antiqui in hoc sunt concordati, quod Deus quinque res disposuit et ordinavit per gradus, quarum nobiliorem in summo gradu collocavit - videlicet materiam primam et formam primam, que est tam quam prima minera omnium; secundo sensus sive intellectus, tercio spiritus, quarto natura celorum, quinto elementa et elementata'. Magrīṭi 1986, book 4, chap. 1, 174. 
when 'mind comes into agreement with the soul'. ${ }^{17}$ The anima mundi thus serves as the glue of the universe, fashioning universal harmony and balance. Towards the end of the first chapter of book 4, the author gives his conclusive definition of 'nature', naming as its characteristic trait the 'perpetual motion' (dä'imat al-harakah) by which corporeal agents are perfected and completed, 'living their potential through the forces of nature' ${ }^{18}$

Furthermore, the Picatrix's philosophy of nature suggests that man can control the various forms of anima mundi and, by doing so, can utilise natural forces to change his destiny and to change his world. Moreover, man can do the same with other parts of nature, shifting their animae toward the higher spheres of the 'first form' and intellect, or closer to the lowest spheres, nature and elements, changing their properties and setting them in motion.

Ficino adopted this new cosmic order to replace Aristotelian metaphysics, echoing Picatrix's argument that 'the relation of the anima mundi to the universal intellect is like the relation of our soul to the active intellect'. ${ }^{19}$ He seems to have projected the intermediary role of a mere anima, which was thought to stand between the soul and body, onto the cosmic order, stressing the omnipresence of the anima mundi. The relationship between the universal body and the universal soul is equal to [that between] our spirit and our active sense. The soul of every being is the medium, Ficino argued, 'by which the divine soul may both be present to the crude body and impart life on it'. ${ }^{20}$ Some of these souls or, as Ficino calls them, 'spiritual bodies', possess a physicality; this is clearly implied in his

17 I present the pertinent Arabic and Latin texts. Although in some places a discrepancy between the two texts occurs, all of my translations are made from the Arabic, which is to be considered the original text.

Magrīịi 1933, book 4, chap. 1, $286 f$.

وجعل النفس فى افق العقل تستمد النور و الحكمة و الفضائل عنه بقوى منه مشاكلة لها تفيض ذلك عليها, وجعل الطبيعة في افق النفس... 'Sensum autem et intellectum posuit in primo circulo descendente ab eodem, qui similiter ab eodem lumine descendit; sciencia etenim et nobilitas virtutis sibi convenientes ei vi ab illo emanantur’. Magrīịi 1986, 174.

18 Magrị̄̂i 1933, 294.

وبعض الاو ائل حدها بانها دائمة الحركة وهي مع ذللك كمال الجسم الفعال الحى بالقوة الطبيعة 'Et una pars sapientum antiquorum sic determinavit: natura est durabilis motus cum quo est perfectio sive complementum corporis agentis et in potencia viva'. Magrīịi 1986, 178.

19 Magrīịī 1933, book 4, chap. 1, 292.

نسبة نفس الكل الى عقل الكل كنسبة انفسنا الى العقل الفعال

'Et spiritus universi est sensus universi. Idcirco omnes substancie incorporee complete in corporibus celestibus moventibus redundant, et hoc propter quietudinem sensus'. Magrīṭi 1986, 177.

20 'Que spiritus necessario requiritur tanquam medium, quo anima divina et adsit corpori crassiori et vitam eidem penitus largiatur'. Ficino 1989, book 3, chap. 3, $256 f$. 
statement that 'besides this worldly body, generally apparent to our senses', some spiritual forces 'escape the capacity of our weak senses'. ${ }^{21}$

Ficino's conclusions regarding the anima mundi appear, as in the Picatrix, toward the end of his book. He explains that the anima mundi is responsible for all natural actions at a distance; standing in for various undetectable physical entities, it causes all motion and rest. 'The anima mundi', he concludes, 'generates and moves the forms of natural things by means of seminal forces it has received from the divine'. The magus, then, can play with such seminal reasons, shifting bodies closer to either the upper or the lower sphere, thus changing their properties and setting them in motion. ${ }^{22}$

But what are the means by which the virtuoso magus can manipulate the actions of the anima mundi? Picatrix argues that the heavenly bodies could be manipulated by talismans designed to suit the properties of each planet. Such talismans, made of materials that accord with the properties of the planet, are fashioned to mirror the planet's qualities. They were used during the periods of the planets' susceptibility to influence.

I have pointed out one of the structural similarities between De vita libri tres and the Picatrix. In fact, Ficino broadly adopts the general scheme of the earlier work. In a chapter titled 'On the Powers of the Rays from Which Images Are Thought to Obtain Their Force', he outlines the ways by which one can control the heavenly bodies through the use of images to attract heavenly influences. Images can concentrate the power of the rays, since 'by the rays' intensity, matter - being dry and far from any moisture - is immediately kindled and, once kindled, is vaporised and dispersed in all directions, blowing out both flames and sulfur'. Not all the physical effects of the rays are detectable, since 'this fire is very dark and, as it were, a sort of flame without light'. ${ }^{23}$ Although al-Kindì's popular De radiis stellarum extensively deals with the role of the sun's rays, it seems that the Picatrix was in fact more readily fitting for his argument, as it points out that as the human body requires a soul to trigger motion so too does a universal soul generate motion at the cosmic level. Both texts stress the mutually dependent connection between heat and light, on the one hand, and motion, on the other:

21 'Quamobrem praeter corpus hoc mundi sensibus familiariter manifestum latet in eo spiritus corpus quoddam excedens caduci sensus capacitatem'. Ibid., book 3, chap. 26, 384.

22 'Itaque per rationes eiusmodi animam mundi facile se applicare materiis, quas formavit ab initio per easdem'. Ibid., 390.

23 'Sed ignem hunc putant valde caliginosum esse et quasi incendium quoddam luminis expers, sicut in coelo extat expers incendii lumen; ignis autem inter coelestem atque infernum lumen cum fervor coniungit'. Ibid., 321. 
bodies are endowed with rays and heat only due to their motion. But why were rays so important to Ficino and his contemporaries?

In introducing astrological notions into the philosophy of nature, Florentine philosophers focused on the following question: Does the influence of the planets exist only in detectable and tangible forms (rays and heat), or does it manifest itself also in intangible ways (forces and radiation)? De vita libri tres played a central role in these discussions. It appeared just as a controversy regarding the truthfulness of astrology and other occult sciences reached its climax. ${ }^{24}$ At the two extremes were Ficino and Pico, the foremost philosophers of Florence, starkly disagreeing as to whether the cosmos was ensouled or unsouled.

In his canonical work, Platonic Theology (Theologia platonica), first published in 1482 and followed by a second edition in 1491, Ficino argued (book iv chap. i) that 'just as universal nature exists everywhere in the universal body, so a universal soul exists everywhere in that universal nature'. ${ }^{25}$ Animated nature is connected to man through incorporeal light, he explains in De vita libri tres, stressing that the anima mundi, which is actually the omnipresent 'incorporeal light', links the tangible part of the world to its soul, the world to the nature of man.

Disagreeing, Pico refused to hypothesise intangible properties with an occult character; preferring instead to stress the sensible and placing the rays of the sun at the center of his natural philosophy. In his attack on astrology, Disputationes adversus astrologiam divinatricem (Disputations against Divinatory Astrology), he reduces the effects of the heavenly bodies to physical properties, thereby detaching man from predetermined cosmic phenomena. Light and heat become the central agents of nature and the angle of the solar ecliptic at different locations is held to be responsible for levels of heat and moisture, which in turn vary living creatures into different species and affect their coming into being and passing away. ${ }^{26}$ He believed that the planets and stars differ from the sun or moon inasmuch as they have very little influence on us, and perhaps none at all. The fetus, he writes, derives its main characteristics from its constituent human seeds and from the climate surrounding the mother, not from the moon and planets. ${ }^{27}$

24 For the cultural context of the controversy over the intangible effects of the planets, see 'Defying Authority, Denying Predestination and Conquering Nature, Florence 1493' in Ben-Zaken 2011, 65-100.

25 'Sicuti se habet natura ad corpus, sic anima ad naturum. Ergo quemadmodum in universo corpore natura universalis est ubique, ita in universa natura ubique universalis est anima'. Ficino 2003, 286.

26 della Mirandola 1946, 1.203.

27 Ibid., 1.269. 
In this regard, Pico only selectively echoes book 2 chapter 3 of the Picatrix, which mentions sages who argued that 'the effects of the heavens and their powers in this world are nothing other than the increase and decrease of heat'. ${ }^{28}$ The Picatrix takes a different approach and additionally stresses that these sages 'did not understand the wonderful occult properties of the planets', since the increase and decrease of heat convey with them spiritual forces that generate motion. Furthermore, whereas Pico conceives of the manifested effects of the heavenly bodies (the sun and the moon) as heat and light, the Picatrix (followed by Ficino) argues that every moving body, even the most distant sphere, the eighth sphere, generates heat, rays, and other undetectable physical-spiritual entities. In this regard, the Picatrix explains that the motion of the heavens is the prime cause of accidental heat, which, in turn, gives life to nature. Whereas Pico argues that the heavenly bodies yield only a physical, measurable influence - rays and heat Ficino relies on the Picatrix to argue that the tangible influence was only the tip of the iceberg, conceiving natural motion as the effect of intangible physicalspiritual entities, that will later, in the seventeenth century, be named forces.

By appropriating, in addition to the Picatrix's practical recipes and talismans, the philosophical framework of the text, Ficino philosophically tames the arguments of natural magic, bringing the occult into the light. The occult, for him, does not mean spiritual entities detached from bodies; on the contrary, he believed that all of the acclaimed spiritual entities were actually physical, playing central roles in generating the motion in the universe. Such spiritual-physical entities underlined the necessary agency and causality in the laws of nature, which come into being in the form of forces of attraction, the radiation of rays, and heat. Thus, Ficino appropriated and reworked arguments from the Picatrix, presenting a middle ground in De vita libri tres. On the one hand, he narrows astrological influences to physical properties, while, on the other, he modifies the arguments of those who rejected astrology by expanding the range of heavenly influence to include intangible physical properties.

The concept of anima mundi played a key role in shedding light on what seemed to be occult knowledge and practices, and, thus, in transforming the occult into a subcategory of natural philosophy. However, the emphasis on anima mundi and its influence on the universe resulted in a view of man as a passive observer of the ways of the universe. Perhaps because Ficino consulted an incomplete manuscript of the Picatrix, referring to it at times as an 'Arabic miscellany', he left out a fundamental component of the complete work (especially books 1, 2,

28 Magrīṭi 1933, book 2, chap. 3, 63. 
and 3 of the Picatrix), the practice of natural magic, as well as any discussion of the virtuoso magician who is able to transform his world. As Perrone Compagni has argued, Ficino's selective usage aimed at creating in De vita a more purified version of the Picatrix that left out materials that might contradict religion. ${ }^{29}$ The Picatrix's other central theme was the practice of philosophy and magic the practical aspect of philosophy, the making of philosophy without philosophy, and the aspiration of making and changing the world by practice, which impacted subsequent generations of readers. The next significant station in the circulation of the Picatrix, Cornelius Agrippa's De occulta philosophia libri tres, brought that issue to the fore.

\section{Legitimising practice: Agrippa's virtuoso}

Whereas Ficino was located at the crossroads of Greek, Arabic, and Hebrew texts on natural magic and philosophy, Agrippa moved restlessly from one place to another, gathering sources and knocking over what seemed to him artificial cultural and disciplinary fences. He could have encountered the Picatrix in several places: Spain, Italy, or even central Europe. ${ }^{30}$ Perhaps it was Johann Reuchlin's borrowings from the Picatrix (The Book of Wonderful Word), presented as a lecture at the University of Dole in 1512, that brought the text to his attention; Vittoria Perrone Compagni has identified in Reuchlin's essay a number of unattributed borrowings from the Picatrix (Perrone Compagni 1977, 317f. and 325).

At any rate, Agrippa also had practical reasons to refer to the Picatrix. While Ficino used the text to promote his project to philosophise natural magic, Agrippa was out to legitimise the practice of natural magic. To that end, he attacked the hegemonic scholastic philosophy of nature for a teleological approach that treated practice as irrelevant to natural philosophy. Taking his convictions into the law court of Metz, he defended a woman from a village named Woippy who was accused of practicing magic, arguing that her work never exceeded the legitimate use of natural forces (Ziegeler 1973, 150-8). At the same time he worked on his alternative program of science, De occulta philosophia libri tres (Three Books of Occult Philosophy), written in the first decade of the century but only published in 1531-1533. He had good reasons to hesitate, since the work legitimised ritual

29 For the reasons for the selective reading and usage of the Picatrix by Ficino, see Perrone Compagni 2011.

30 Darmstadt, Universitäts- und Landesbibliothek, 362 (630); Vienna, Österreichische Nationalbiblothek, 3317 (Philos. 156); Magrị̣̂i 1986, xvi-xvii. 
magic and emphasised the virtues and skills necessary for the would-be magician. Cautious as to when and where he published, Agrippa also wrote dedications that aimed to reduce the danger of ecclesiastical condemnation. Furthermore, to soften the landing of his bold magnus opus, he preceded its publication with another book in which he openly promoted natural magic as the prime program for the sciences, transforming the magician into an experimental virtuoso. The Picatrix suited such an enterprise.

Whereas the previous generation of natural magicians tried to mix natural magic with scholasticism, Agrippa boldly treated the two bodies of knowledge as conspicuously contradictory. His De incertitudine et vanitate scientiarum et artium (On the Uncertainty and Vanity of the Sciences and the Arts), dated 1527, took aim at the hegemonic scholastic philosophy of nature. In the preface he calls the attention of the reader to the tyranny of scholasticism: 'I find', he writes, 'a most detestable custom that has invaded all or most schools of learning to swear their students never to contradict Aristotle, Boetius, Thomas, Albertus or some such school deity: from whom if anybody would even slightly divert, he would be proclaimed heretic, a criminal against the holy sciences deserves only to be consumed in fire and flames' ${ }^{31}$ Scholasticism, thus, 'captivates the minds of students and authors, depriving them of the liberty of searching after and following the truth', ${ }^{32}$ turning 'Arts and Sciences' into a destructive force. For Agrippa, traditional study of the sciences entailed working within institutional divisions, specialisation which eventually yielded a narrowed view of science. Natural magic, by contrast, was a multicultural field, an interdisciplinary mixture of theory and practice. As such, enthusiasts such as Agrippa believed that every human being is able to discover and manipulate the hidden secrets of nature.

De incertitudine et vanitate scientiarum et artium was written to break through the wall of scholasticism; it drove toward that end by cynically surveying its derivative sciences. In chapters 41, 42, and 43, Agrippa appraises and differentiates magic, natural magic, and mathematical magic, presenting them as the products of intersecting cultural currents that he traces from antiquity up to his own day. The noun magus, for instance, came from Persian and

31 'Praeterea in multis ac ferme omnibus gymnasijs peruersus mos, ac damnabilis cosuetudo inoleuit, quod initiandos discipulos iureiurando adigunt Aristoteli aut Boethio, aut Thomae, aut Alberto, seu alio cuiuis suo scholastico Deosese nunquam repugnaturos: a quibus se quis latu unguem diuersum senserit, hunc haereticum scandalosum, piarum aurium offensiuum, igne flammisque absumedum proclamant'. Agrippa von Nettesheim 1575, Ad Lectorem.

32 'Denique quàm impia tyrannis, captiuare ad praefinitos autores studiosorum ingenia, et adimere discipulis libertatem indagandae et sequendae veritatis'. Agrippa von Nettesheim 1575, Ad Lectorem. 
'signifies a priest, wise man, or philosopher [who worked with] both natural magic and mathematical magic'. ${ }^{33}$ In chapter 42, Agrippa defined natural magic as the 'highest power of natural science, the active part of natural philosophy, which by means of natural virtues, applied jointly and felicitously, elicits admirable operations'. The Ethiopians and the Indians - the first to use 'the virtue of herbs, and stones, and other natural things' - set the standard. They also defined the role of the magic virtuoso, which was to consider 'the strength and force of natural and celestial beings, and having worked diligently to discover their affections, [render] visible the hidden and concealed powers of nature'. Among these masters Agrippa names Zoroaster and Hermes Trismegistus, but the only authority whose biography he set down is 'the author of the book to Alfonsus, written under the name of Picatrix, who into natural magic mixes much superstition, as indeed the rest have done'. ${ }^{34}$

The Picatrix, however, argues that the successful natural magician, the virtuoso, had to acquire not only a knowledge of the natural world but also the skills needed to extract such secrets publicly. 'You should know', the text stresses, 'that the practice of magic ['amal, experimenta] discovers the secrets of sciences; by work and experiments doubts are unfolded'. ${ }^{35}$ If there is an agency in nature that causes motion and rest, the book indicates, then man carries within himself such agency and, through self-reflection, he discovers the 'virtue that cares for and governs his body', employing experiments to extend this insight into the realm of nature.

Agrippa borrowed this line of argumentation and used it to set the foundation for his greatest work, De occulta philosophia, affirming natural magic as a

33 'Exigit etia hic locus ut de Magia dicamus: nam \& ipsa cum Astrologia sic coniuncta, atq; cognate est, ut qui Magia sine Astrologia profiteatur, is nihilagat, sed tota aberret via. Suidas magiam à Magusies \& nomen, \& originem traxisse putat. Comunis opinion est nomen esse Persicum cui adstipulantur Porphyrius, \& Apolieus, \& significare eorum lingua idem quod facerdotem sapiente sive Philosophum. Magia itaque omnem philosophiam physicam, \& mathematicam complexa etia vires religionum illis adiungit: hinc Goetiam, \& Theurgiam in sequoq continet. Qua de cosa Magiam plerique bifariam dividunt in naturalem videlicet \& caeremonialem'. Agrippa von Nettesheim 1575, chap. 41.

34 'Author libri ad Alphonsum, sub picatricis nomine editus, qui tamen una cum naturali magia plurimum superstitiones admiscet quod quidem fecerunt \& alii'. Agrippa von Nettesheim 1575, chap. 42.

35 Magrīṭi 1933, book 3, chap. 12, 282.

$$
\text { و اعلم أيها الباحث أن العمل يخرج مكنون العلوم وبه تنحل الثكوك فانه عند حصول معرفة المطلوب تنحل الثكوك }
$$

'Illum autem qui in hac sciencia se intromittere intendit scire oportet quod propter opera et experimenta que fiunt in hoc mundo scienciarum profunditates et secreta sciuntur, et ex operibus et experimentis solvuntur dubia'. Magrīịi 1986, book 3, chap. 12, 170. 
science based on firsthand explorations of the secrets of nature. For him, the Picatrix offered both lessons in natural magic and the historical and philosophical authority for the primacy of induction in the exploration of nature.

Agrippa mentions the Picatrix several times in De occulta philosophia and in a few additional places he ascribes its content to 'Arabs'. For instance, in book 1, chapter 12, titled 'How Superior Bodies Control Inferior Things, and How the Stars and Signs Control the Bodies, the Actions, and the Dispositions of Men', Agrippa writes that, 'according to the doctrine of the Arabs, the Sun rules over the brain, the heart, and the rest of the feeling organs' ${ }^{36}$

However, it is when Agrippa offers his description of the virtues and skills possessed by those who practice natural magic that he draws most tellingly on the Picatrix. Early in his discourse, Agrippa explains that its purpose is to show 'how magicians collect virtues from the threefold world'. His decision to divide his treatise in three parallels the structure of the universe, made up as it was of elementary, celestial, and intellectual matter. The role of the natural magician, therefore, is to climb a ladder of philosophy by seeking 'after the virtues of the elementary world, relying for assistance on natural philosophy in the various combinations of natural things, then the [virtues of the] celestial world via the rays, and their influences thereof, according to the rules of astrologers and doctrines of mathematicians'. By so doing the natural magician is practically 'joining the celestial ventures to the elementary world' ${ }^{37}$

Agrippa subsequently elaborates on the qualifications of the virtuoso. Magic necessarily relies on other disciplines. 'Whoever wishes to study natural magic', Agrippa suggests, must be knowledgeable about natural philosophy, 'wherein are discovered the qualities of things, and in which are found the occult properties of every being'. He also has to be skillful in mathematics, 'and in the aspects, and figures of the stars, upon which depend the sublime virtue and property of everything'. He has to be learned in theology, 'wherein are manifested those immaterial substances'. Only after climbing these rungs on the ladder of philosophy will he be 'able to understand the rationality of magic'. Agrippa concludes that natural magic addresses not only agency in the world but also acts as a mediator between different bodies of knowledge, since 'there is no world that is the

36 'Scias itaque iuxta Arabum traditionem Solem praeesse cerebro et cordi, <femori, medullis, oculo dextro et spiritui vitae>'. Agrippa von Nettesheim 1992, book 1, chap. 22, 129.

37 'Hinc elementalis mundi vires varris rerum naturalium mixtionibus a medicina et naturali philosophia venantur; deinde coelestis mundi radiis et influxibus iuxta astrologorum regulas et mathematicorum disciplinas coelestes virtutes illis connectunt'. Ibid., book 1, chap. 1, 85 . 
product of magic alone, nor any labor that is exclusively magical, that does not comprehend these three faculties' ${ }^{38}$

Agrippa may have drawn from the Picatrix the notion of the magus as mixing not only matter but also intellectual disciplines and cultural practices, a view of natural magic as interdisciplinary, while the magus is seen as an agent connecting the upper and lower worlds, the angelic and the celestial worlds to the elementary world. This magical virtuoso brings together distinct bodies of knowledge (pertaining to each world), giving natural magic the crucial role of mediating and connecting the various detached disciplines of arts and sciences. The Picatrix stresses that the magus, in the practical process of making images and miracles, 'produces techniques and skills' and is able to understand forms of things in nature by virtue of the exclusive human nature (which includes all other forms in nature): 'the talismans are more powerful than any other optional thing since they were fashioned according to the universal nature. They (talismans) are like miracles since they use the general form and substance of nature, which in turn make miracles and other marvels'. If the talismans include the universal form of nature, then the craftsman, the magus, who created them encapsulates the structure of the universe, since 'the image of man contains of the image of the spirit of the universe'. ${ }^{39}$ Agrippa counterpoises forms for acquiring knowledge: the medieval scholastic vita contemplativa versus the occultist vita activa. Since man was created in the form of God, the magus, the individual practitioner, is able through an active exploration of nature to connect to the spirit of the universe.

One finds echoes of the Picatrix in other aspects of Agrippa's work too. It appears to have informed his thinking on how the virtuoso connected different worlds and crossed disciplinary boundaries. The magus not only alters the mixture of matter in this world, he also connects matter, bodies, spirits, and forms, to their celestial origins - to the single universal source of the anima mundi. He does this by making images and measuring matter.

38 'Nullum enim opus ab ipsa magia perfectum extat nec est aliquod opus vere magicum, quod tres facultates non complectatur'. Ibid., book 1, chap. 2, 86-9.

39 Magrīịi 1933, book 1, chap. 5, 85.

ان الطلسمات انفذ من الاختيارات لانها مستعملة بطبيعة الكل وهي كالمعجز لاستعمالها الخواص الطبيعية وذلك ان الخواص تفعل

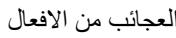

The Latin translation mistakenly marked this paragraph in chapter 6, whereas in the original Arabic text it is the end of chapter 5.

'Operatur industria et arte. et similiter ab aliis industria et arte retrahitur. Et invenit magisteria subtilia et eorum subtilitates,et facit miracula et ymagines mirabiles. et scienciarum formas retinet....Et generalis forma hominis est archa forme spiritus in generali. et spiritus generalis est archa sensus generalis. et sensus generalis est archa luminis unde sensus procedit'. Magrịtị 1986, book 1, chap. 6, 26 f. 
In De occulta philosophia, the making of images is the most evident trace of Agrippa's reading of the Picatrix. He echoes his source at one point, writing, 'The magicians affirm that both by the mixture and application of natural things and by images, seals, rings, glasses, and some other instruments, if [the events take place] opportunely under a specific constellation, a celestial illustration may be made, and some wonderful thing may be received by images'. Since the beams of the celestial bodies are animated, they 'transport marvelous gifts, and a most violent power', and the image can attract and manifest these 'wonderful powers'. In order for the image to become more powerful it has to correspond to the natural properties of the objective heavenly body and also to have its form. ${ }^{40}$

Later on, Agrippa mentions his sources, saying, 'There are besides in the zodiac thirty-six images, according to the number of the faces' of which ancient mathematicians - and later 'the Arabians' - wrote. ${ }^{41}$ He further echoes the Picatrix in a description of the planets. The image of Saturn, imprinted on a lodestone, shows 'a man the face of a hart and the feet of a camel, seated on a dragon, holding in his right hand a scythe, in his left an arrow'.42

Moreover, the Picatrix links the practice of natural magic with the mathematical and quantifying practices that enabled the virtuoso to discover the hidden laws of nature, endowing him with the ability to channel a natural force to the use of man. Quantity is the foundation of this science, for magic is part of the quadrivium. Quantity is divided into two parts, corresponding to geometric and algebraic laws of nature: 'continuous quantity (line, surface, body, time, and place) and discrete quantity (numbers and words)'. ${ }^{43}$

40 'Coelestium enim corporum radii animati, vivi, sensuales, dotes mirificas potentiamque vehementissimam secum ferentes, etiam repentino momento ac subito tactu mirabiles in imaginibus imprimuntur viresetiam in materia minus apta; efficaciores tamen largiuntur imaginibus virtutes si non ex qualibet, sed certa materia fabricentur, cuius videlicet virtus naturalis cum specifica simul opera conveniat figuraque imagines similis sit figurae coelesti'. Agrippa von Nettesheim 1992, book 2, chap. 35, 251 .

41 'Post quem scripserunt de illis etiam Arabes'. Ibid., book 2, chap. 37, 354.

42 'Faciebant enim ex operibus Saturni, ipso ascendente, in lapide qui magnes dicitur imaginem hominis cervinum valtum et cameli pedes habentis, super cathedram vel draconem sedentis, in dextra falcem, in sinistra sagittam tenentis; quam quidem imaginem sperabant sibi ad vitae longitudinem profuturam'. Ibid., book 2, chap. 38, 358.

43 Magrịtịi 1933, book 2, chap. 7, 96.

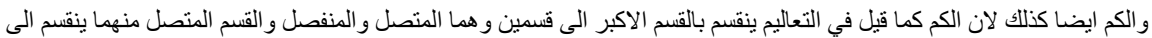

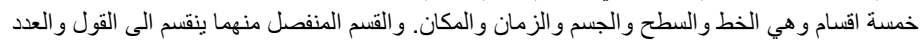

'Et similiter quantitas est radix istius sciencie eo quod ipsa in quadrivio operatur. Secundum suam primam divisionem dividitur in duas partes, que quidem partes sunt ipsa quantitas continua et discreta. Quantitas vero continua dividitur in partes quinque. que sunt linea. superficies. corpus. 
In the same vein, Agrippa elaborated on the quantification of natural magic, saying that mathematical learning was a 'necessity' since all things 'are governed by number, weight, measure, harmony, motion, and light' ${ }^{44}$ By combining expertise in natural philosophy and mathematics - by using the laws of arithmetic, music, geometry, optics, and astronomy, together with measuring tools the magician virtuoso 'may do many wonderful things' ${ }^{45}$ He may, for instance, produce 'images that speak and foretell things to come'. Above all, 'numbers, that have more of form in them, are effective' at finding their counterparts in the celestial world, which leads to discovering 'the effects of good and bad things'. Thus, Agrippa concluded, images and numbers both described the forms of nature. ${ }^{46}$

Agrippa's and Ficino's readings of the Picatrix converged around one particular image: the sun. Both were drawn in by the idea that talismans functioned as did the sun, and that the sun is the center of influences, the source of all spiritual-physical entities. If one could create an image that encapsulated the sun's qualities, it would, naturally and ineluctably, possess great practical powers.

The Picatrix argues that heavenly bodies influence nature through undetectable spiritual-physical entities that can be captured and used by means of images. It also argues that the sun, the source of those entities, governs the whole universe by its rays. But which natural images, forms not made by man, could

tempus et locus; et quantitas discreta dividitur in duas partes, videlicet numerum et verbum'. Magrītịi 1986, book 2, chap. 7, 58.

44 'Mathematicae disciplinae ad magiam tam sunt necessariae atque cognatae ut qui hanc absque illis profiteatur, is tota aberret via frustraque laboret minimeque desideratum adsequatur effectum. Quae cunque enim sunt et fiunt in istis inferioribus naturalibus virtutibus, omnia haec 'numero, pondere, mensura', harmonia, mootu et lumine fiunt atque reguntur et omnes res, quas videmus in istis inferioribus, habent radicem et fundamentum in illis'. Agrippa von Nettesheim 1992, book 2, chap. 1, 249.

45 'Hinc magus, expertus philosophiae naturalis et matheseos, cognitisque mediis scientiis ex his utrisque existentibus, arithmetica, musica, geometria, optica, astronomia, et quae de ponderibus, mensuris, proportionibus, articulis et iuncturis scientiae sunt, cognitisque etiam mechanicis artibus ex illis resultantibus, quid mirum si supra caeteros homines arte et ingenio praecellens, mirabilia multa operetur, quae etiam prudentissimi quique et scientissimi valde admirentur?' Ibid., book 2, chap. 1, 250.

46 'Loquuntur autem de numero rationali et formali, non de materiali, sensibili sive vocali nuero mercantorum ... numerum naturalem et formalem et rationalem vocant, ex quo magna sacramenta emanant tam in naturalibus, quam divinis atque coelestibus. Per illum havetur via ad omnia scibilia indaganda et intelligenda; per illum havetur proximus accessus ad prophetiam naturalem: atque ipse abbas Ioachim in prophetiis suis alia via quam per numeros formales non processit'. Ibid., book 2, chap. 1, 253. 
perfectly capture such influences and win universal appreciation from all religions and cultures?

In book 3, chapter 5, the Picatrix offers a rather peculiar injunction for a presumably Muslim writer. The author give practical instruction to the magus on the process of preparing talismans: 'Then we are making seven forms [talismans] on stones, each one in the form of the hour of the planet, [although the forms vary from planet to planet] they all convey the form of the cross, which is the mastery form of all the planets'. The cross holds a spiritual power since it 'connects to everything similar to its form and resists everything that is dissimilar to its form', universally affecting all objects in nature. The Picatrix tackles a practical consideration - how to transform three-dimensional objects of nature, and their functional relations, into a two dimensional representation on talismans? In coping with this problem the text makes a radical implication - the form of the circle merely describes the location of objects in space whereas only linear forms, like the cross, can describe fractions of rays, their function, power, and influences. The text alleges physical and geometrical considerations: the sun rays are understood in terms of their length and breadth, formal qualities also found in the cross, 'we drew the form of the cross since every planet carries its [cross] form, since every physical body has a surface, and the surface is made of length, breadth, and the form of breadth and length is actually the cross itself. And for this reason we hold the cross [as a universal form] since the spirits do not resist to it'. Taking this a step further, the Picatrix describes the cross as possessing 'a universal mastery' in manipulating the influences of the heavenly bodies, 'we said that there is no person who is not subjected to the rule of the seven planets, and therefore, if the spirits connect to the image of the cross then it gives the man who carries it bravery and power' ${ }^{47}$ Since light plays a role as an agent between

47 Magrīṭī 1933, book 3, chap. 5, 184-185.

من كل حجر من هذه الاحجار صورة ساعة الكوكب الذي ذللك الحجر من قسمته وتكون هذه السبع الصور حاملة للصليب

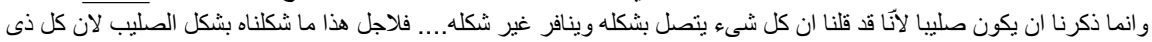

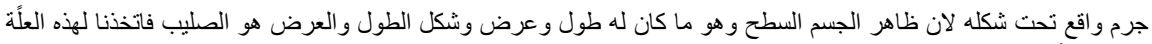

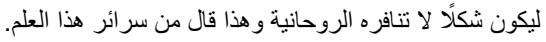

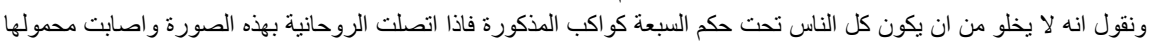
كانت له عزة وقوة انه لانو

'Causa vero propter quam dicimus hanc figuram in forma crucis fiendam esse est quemadmodum diximus, scilicet quod omnia in suis viribus colligantur figuris ex sua qualitate existentibus, et fugiant a contrariis. Et nos querimus potencias spirituum planetarum ut sue figure coniungantur, et non cognoscimus figuram spiritus nec ad ipsam attingere possumus experimento nisi per figuram hominis, animalis vel alterius rei. Et ideo concluditur quod omnis virtus predictorum maxi me consistit in figuris. Idcirco, quia videmus omnes figuras et formas arborum et plantarum esse in suis figuris diversas necnon et figuras animalium et similiter minerarum, qua propter 
objects in nature, drawing linear lines can describe the functional influential relations between objects and the form of a cross thus utterly encapsulates such relations.

Ficino echoes the Picatrix, observing (3.18) that whereas some saw the circle as the fittest symbolic representation of the heavens, 'the more ancient authorities, as we have read in a certain "Arabic miscellany", preferred above all other figures the cross'. He emphasises that 'bodies apply their power as soon as it has diffused to a plane, and a primary plane is best marked out by a cross'. The cross, more than any other image, 'possesses length and breadth and of all figures it possesses the highest degree of rectilinearity, and it has four right angles'. Since the effects of the celestials appeared most strongly 'through the perpendicularity of rays and of right angles', the stars are much more 'potent when they occupy the sky's four angles casting their rays upon each other to form a cross'. This was why 'the ancients said that the cross served as a receptacle for the strength of the stars; it therefore possessed the greatest power among images, receiving the forces and spirits of the planets. ${ }^{48}$

In De occulta philosophia Agrippa adopts a similar line. In one of the few places (2.23) in which he alludes to the Picatrix, the cross is presented as the universal figure of natural magic: 'The Arabs confirmed that the figure of the cross has very great power, that it is the strongest of receptacles for celestial powers and intelligence'. He adds that the cross 'is strengthened by the straightness of angles and rays; stars are most potent when they stand in the four corners of heaven and the projection of their rays forms a cross, ${ }^{49}$

nullo modo cognoscere possumus proprie figuras ipsorum spirituum planetarum, ideo sapientes huius artis antique tamquam universalem figuram crucem elegerunt, et hoc propter quod omnia corpora apparent sua superficie et quia superficies figurarum habet longitudinem et latitudinem, et figura longitudinis et latitudinis proprie consistit in cruce. Idcirco hanc figuram tam quam universalem magis tram diximus in talibus operandi et tamquam receptricem virium spirituum planetarum eo quod aliqua figura non divertitur ab ea’. Magrīịi 1986, book 3, chap. 5, 107.

48 'Postermi quidem imaginum auctores universam earum formam ad coelisimilitudinem accepere rotundam. Antiquiores autem, quemadmodum in quodam Arabum collegio legimus, figuram cruces conctis anteponebant, quia corpora per virtutem agunt ad superficiem iam diffusam. Crucem ergo veteres figuram esse dicebant tum stellarum fortitudine factam, tum earundem fortitudinis susceptaculum; ideoque habere summam in imaginibus potestatem, ac vires et spiritus suscipere planetarum'. Ficino 1989, book 3, chap. 18, 334.

49 'Figuram autem crucis Aegyptii atque Arabes summam potentiam habere confirmabant quodque sit omnium coelestium virium atque intelligentiarum firmissimum receptaculum, quia ipsa sit figura omnium rectissima, continens quatuor angulos rectos sitque prima superficiei descriptio, habens longitudinem et latitudinem; dicebantque eam rectitudinem angulorum atque radiorum resultat; suntque stellae tunc maxime potentes, quando in figura coeli quantuor 
Since astronomers focused on the location of planets and on the structure of the universe, the mathematical language used to describe them ought to be geometry, with the circle as its prime form. Despite this, Picatrix, Ficino, and Agrippa, as well as other thinkers working on natural magic, focused on the functioning of the heavenly bodies, the ways in which they linearly influence each others' forces and rays. They thus claim that the proper mathematical language with to describe these bodies and forces ought to be a geometry of fractions of linear lines, with the cross as its prime form.

Uniting the notions of the anima mundi, the centrality of the sun, and the role of the virtuoso through the form of the cross, which they made a universal and natural image, Picatrix, Ficino, and Agrippa offered a religious and political symbol under which society could be organised. Thus, the readers of the Picatrix went beyond philosophical discussions, laboring to legitimise the theory and practice of natural magic. Furthermore, they laid the foundations for a new discussion in which natural magic could serve as an ideological framework for bottom-up political and scientific utopias, centered around the symbols of the sun and the cross. Such societies had existed, they claimed, in the ancient East.

\section{Politicising magic: Campanella's 'Republic of supernal spirits'}

Tommaso Campanella never explicitly mentions the Picatrix but his familiarity with it can be found in the book's structure, places mentioned, and reference to particular ancient cultural practices. While Ficino lived at the center of the Renaissance circulation of texts, and Agrippa was a wandering 'center of circulation', Campanella lived in a dungeon in Naples; how he came to read Picatrix remains a mystery. We have some indications that early in his life, before he was imprisoned, he practiced astrological magic, as is implied in Atheismus triumphatus (Atheism Conquered), which he wrote from 1606 to 1607. Moreover, since he alludes to the Picatrix in La città del Sole (The City of the Sun), which he wrote in 1601, it seems likely that Campanella encountered one of the circulating manuscripts of the text prior to his imprisonment in 1598, about a century after Ficino first mentioned it in print.

obtinent cardines atque radiorum suorum in si invicem proiectione crucem constituunt'. Agrippa von Nettesheim 1992, book 2, chap. 23, 319f. 
Campanella was perhaps the last Renaissance intellectual who considered notions of natural magic in philosophical terms. He was surely aware of his historical position, reflected in his cautious attitude, and selectively mentions sources that fit with the religious and cultural circumstances of his time. An indication of why Campanella would not have been quick to unveil his debt to the Picatrix is found in the title of his work on astrology: Six Books of Astrological Matters, in Which Astrology, Purged of All the Superstitions of the Arabs and Jews, Is Treated Physiologically, in Accordance with the Holy Scriptures and the Doctrine of St. Thomas, Albert, and the Greatest Theologians; So That They May, without Suspicion of Evil, Be Read with Profit in the Church of God. ${ }^{50}$ To deflect a familiar Christian criticism of astrology, he proleptically attacked the very works on which he drew heavily. Campanella's sources, he explained, would instead be Persian, Egyptian, and Babylonian.

Although the Picatrix is not mentioned by name, its implied presence is detectable. In the first chapter of book 4, the Picatrix discusses the spirits of objects and their senses, stressing that 'matter is divided into two parts, that is to say, the spiritual and the corporeal', ${ }^{51}$ and that sensus mundi is substance equally distributed in all bodies, [something] distinct from matter,52; and finally that God 'planted it in those bodies' but it is intangible, though physically manifest in the sun's rays. ${ }^{53}$ In De sensu rerum et magia (On the Sense of Things and on Magic), which appeared in 1620, Campanella not only imitated the structure of the Picatrix but also reformulated its arguments, particularly those regarding the concept of sensus mundi - the intellect, soul, or spirit that resides in matter and is the prime cause of natural motion. Echoing the Picatrix, Campanella writes that the Arabs conceive of space as a godly entity sustaining all things. 'Without contradictions he lovingly receives all things, and nothing dies for him, but the body is dead in respect of it'. According to his Arab sources, natural bodies cannot be dead objects but are an extension of the being of God. 'The attraction is the sense of space', thus objects have senses that rely on the sensus mundi, namely the visible sun, to connect them to the anima mundi and to propagate and receive

50 Campanella 1629.

51 Magrīịī 1933, book 4, chap. 1, 288.

أن ألجوهر مع هذا ينقسيم قسمين روحاني وجسماني.

'Sed materia dividitur in duas partes, videlicet in spiritualem et corporalem'. Magrīịi 1986, book 4, chap. 1, 175.

52 'est substancia equali pondere omnibus suis partibus, a materia remota'. Magrịtīi 1986, book 4, chap. 1, 177.

53 'et plantavit earn in istis corporibus que sunt secundum lumen Solis, quod est ex eo qui per radios ipsa corpora attingit’. Magrîtī 1986, book 4, chap. 1, 178. 
spirits, forces, and other influences, which in turn transform matter and generate motion and rest. ${ }^{54}$

But more than any other work, it is Campanella's La città del sole (The City of the Sun), his scientific and political utopia, that bears the impress of the Picatrix. Here he mingles natural magic, talismanic art, experimental science, and heliocentrism by way of cross-cultural exchanges. He sets the work on the mythical island of Taprobane in the Indian Ocean; there one can find 'Adam's footprint after his fall from grace'. The inhabitants, practitioners of natural magic, had 'come from India, flying from the sword of the magi'. The Solaris, as these people were called, followed Brahma and Pythagoras, and children were inculcated with a social ethic at a tender age, ensuring that the political order arose from the bottom up (Campanella 1995, 6f.).

This very idea occurs in the Picatrix. In a pendant to comments on the cross-cultural transmission of natural magic, the author mentions that from the ancient Chaldeans up to his own time and place people had described a utopian city of philosophers, a community of sun worshippers who employed talismans to guarantee political order. The Chaldean magi asserted that, 'Hermes built, in the east of Egypt, a city twelve miles in length, in which he set a citadel that had four gates on its four sides. At the eastern gate he put the image of an eagle, at the western gate the image of a bull, at the southern gate the image of a lion, and at the northern gate he built the image of a dog'. The purpose of these images was to attract 'certain spiritual essences' that would act as gate keepers, 'allowing no one to pass through the portals without their permission'. At the summit of the citadel, Hermes built a tower, which attained a height of thirty cubits, and on the summit of the tower he set a sphere, 'the color of which changed with each of the seven days'. Around the city he placed diverse and changing images, by means of which the inhabitants were made 'virtuous and freed from sin, wickedness, and sloth'. The name of the city was Adocentyn (madinat al-Ashmūninn), and its people were 'deeply learned in the ancient sciences, their profundities and secrets, and in particular in the science of astronomy'. ${ }^{55}$

54 'Ex quo Arabes quidam putarunt spatium esse Deum ipsum,quia omnes sustinet res, nullis contrariatur omnesque recipit benigne, nec unquam moriuntur illi, \& perillud, sed hoc corpus \& per modo respectu illius corporis mortuum est'. Campanella 1623, 25.

55 Magrīṭī 1933, book 4, chap. 3, 310.

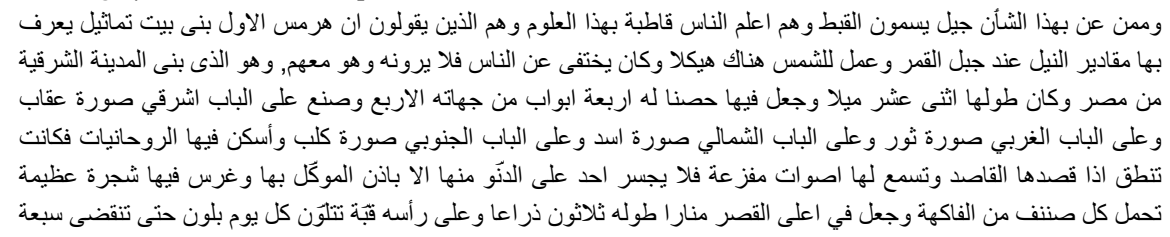


Adocentyn stood at the crossroads of a number of cultures, as does Campanella's utopian city. The parallels continue: Campanella describes the republican order of the City of the Sun as being constituted through the abstraction of the forces of nature into talismanic images. On the top of a civic dome, 'nothing is seen over the altar but a large sphere, upon which the heavenly bodies are painted, and another globe upon which there is a representation of the earth'. The temple has 'seven golden lamps always burning, and these bear the names of the seven planets.' 56

The governing power of the sun and its centrality, and the cross as its geometrical representation, led to the notion that the heavenly bodies are the natural republic, harmonically aligning the laws of nature with the laws of religion and society. The perfect earthly republic will, therefore, have to be organised along the same tenets. In the Picatrix such a political application of natural magic is clearly

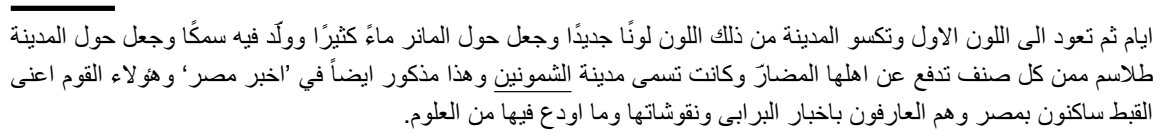

'Sunt etenim magi qui in hac sciencia et opere se intromiserunt Caldei; hinamque in hac perfectiores habentur sciencia. Ipsi vero asserunt quod Hermes primitus quandam domum ymaginum construxit ex quibus quantitatem Nili contra Montem Lune agnoscebat; hic autem domum fecit Solis. Et taliter ab hominibus se abscondebat quod nemo secum existens valebat eum videre. Iste vero fuit qui orientalem Egipti edificavit civitatem cuius longitude duodecim miliariorum consistebat, in qua quidem construxit castrum quod in quatuor eius partibus quatuor habebat portas. In porta vero orientis formam aquile posuit, in porta vero occidentis formam tauri, in meridionali vero formam leonis, et in septentrionali canis formam construxit. In eas quidem spirituales spiritus fecit intrare qui voces proiciendo loquebantur; nec aliquis ipsius portas valebat intrare nisi eorum mandato. Ibique quasdam arbores plantavit, in quarum medio magna consistebat arbor que generacionem fructuum omnium apportabat. In summitate vero ipsius castri quondam turrim edificari fecit, que triginta cubitorum longitudinem attingebat, in cuius summitate pomum ordinavit rotundum, cuius color qualibet die usque ad septem dies mutabatur. In fine vero septem dierum priorem quem habuerat recipiebat colorem. Illa autem civitas quotidie ipsius mali cooperiebatur colore, et sic civitas predicta qualibet die refulgebat colore. In turris quidem circuitu abundans erat aqua, in qua quidem plurima genera piscium permanebant. In circuitu vero civitatis ymagines divers as et quarumlibet manerierum ordinavit, quarum virtute virtuosi efficiebantur habitantes ibidem et a turpitudine malisque languoribus nitidi. Predicta vero civitas Adocentyn vocabatur. Hic autem in antiquorum scienciis, earum profunditatibus et secretis atque in astronomie sciencia erant edocti'. Magrịịi 1986, book 4, chap. 3, 188f.

56 'Sopra l'altare non vi è altro ch'un mappa-mondo assai grande, dove tutto il cielo è dipinto, ed un altro dove è la terra. Poi sul cielo della cupola vi stanno tutte le stelle maggiori del cielo, notate coi nomi loro e virtù, c'hanno sopra le cose terrene, con tre versi per una; ci son I poli e I circoli signati non del tutto, perché manca il muro a basso, ma si vendono finiti corrispondenza alli globbi dell'altare. Vi sono sempre accese sette lampade nominate dalli sette pianeti'. Campanella 1995, 3f. 
in place. The text states, 'The Nabatean sages have said that the power and works of the heavens and stars originate in the sun... . The fixed stars are the sun's handmaidens; they serve, obey, and are humbled by him'. ${ }^{57}$ In Atheismus triumphatus, Campanella says of the sun: 'It is endowed with a vivid and simple beauty; it is the nobler cause of lower things [...] continually benefitting us by pouring out light, heat, and influences, generating, changing, producing all things; on account of all this the pagans could easily be led to think that it is a god' ${ }^{58}$ He takes the idea a step further in La città del Sole, pointing out that the Solaris [just like the Nabateans] worship the Sun and in their morning prayer direct their prayers to the east, calling the Sun 'our father in heaven'. Further, they 'honour the Sun and the stars and conceive them as living bodies, icons of God and celestial temples; though, they do not worship the stars, but mostly the Sun. [...] they worship God under the image of the Sun, which is the icon of God and his face and living image, from which comes light and heat to everything. And indeed, they built a temple designed like a lighthouse Sun, in which priests pray to God in the Sun and stars'. ${ }^{59}$ The City of the Sun functions as a republican polity that is ordered through talismanic symbols, magical worship, and education aimed at developing natural talents;

57 Magrīṭī 1933, book 3, chap. 8, 229.

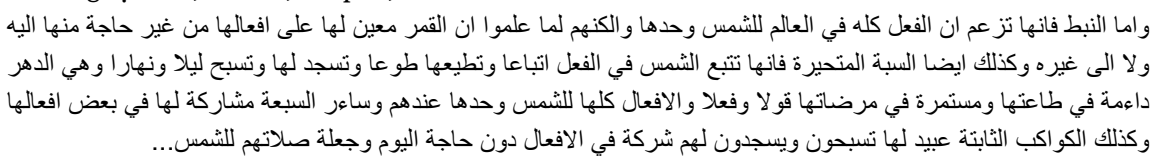
'Neptinorum sapientes dixerunt quod potencie et opera celorum et stellarum sunt Solis simpliciter, et ideo quia vident et intelligunt quod Luna iuvat eum (hoc est, quantum in suis effectibus), non quod Sol indigeat ea nec aliis planetis; et similiter alii quinque planete sequuntur Solem in suis effectibus et obediunt et humiliantur eidem, et secundum disposiciones Solis in predictis effectibus procedunt. Et ideo omnes effectus sunt in Sole secundum eorum opinionem primitus radicati, ceteri vero sex planete iuvant eum in suis effectibus. Et similiter stelle fixe ancille sunt eidem, serviunt, obediunt et humiliantur ei, et in suis effectibus iuvant ipsum, non propter indigenciam quam habet ex eis. Et he gentes Soli hanc oracionem facere solebant'. Magrītī 1986, book 3, chap. 8, 138.

58 'Minore tandem reprebensione dignos deprehendi eos, qui adorant Sidera, Caelum \& Solem: quonia m hac portiones Mundi se onstendunt, à corrupione distantes, \& pulcheritudine vivida, simplicique donatae sunque nobiliores rerum interiorum causae, \& in sublimi regione degunt, continuò beneficientes nobis, lucem essundendo, calorem , \& influentias: generando, alterando Omnia que producendo: qua ob res magis movere possunt Gentes ad credendum quòd sint Dii'. Campanella 1631, 111.

59 'Onorano il sole e le stelle come cose viventi e statue di Dio e tempi celesti; ma non l'adorano, e più onorano il sole. Nulla creatura adorano di latria, altro che Dio, e però a lui serveno solo sotto l'insegna del sole, ch'è insegna e volto di Dio, da cui viene la luce e 'lcalore ed ogni altra cosa. Però l'altrare è come un sole faro, e li sacerdoti pregano Dio nel sole e nelle stelle'. Campanella 1995, 35f. 
its structure mirrors that of the universe. This became an idée fixe for Campanella and in his other writings, such as Astrologia, he repeats that, 'I certainly have the faith that the stars are a republic of supernal spirits', ${ }^{60}$ echoing the Picatrix's (2.10) description of the heavenly bodies as a celestial commonwealth centered around the sun. The talismanic form of the Sun, the Picatrix says, is a king, ${ }^{61}$ and just like a king it governs from the center its kingdom. The plants and the stars derive in the most efficient way their light, heat, motion and influences from the sun, making the celestial commonwealth a representation of perfect natural order.

The City of the Sun, Campanella's homage to the political practices of the East, is an attempt to revisit Adocentyn, a cultural alternative to scholastic Europe, a place where natural magic builds up rational, meritocratic, scientific, and state institutions. ${ }^{62}$ In a sense, Campanella follows the Picatrix's description of Adocentyn, which Pico echoes in asserting that the Persian kings trained their

60 'Firmissimè credo, quod \& gentibus omnibus credibile videtur, teste Philone \& Origene, sydera esse Respub. Spirituum supernorum, cum in mundum corporcum ex mentali egrediantur. Nam activissima res est ignis lucidissima, sensitivissima, idcircò maximè conveniens spititibus potestate \& sapientia decoratis'. Campanella 1638, III, XI, ix, i, 52.

61 Magrīịī 1933, book 2, chap. 10, 108.

صورة الملك جالس على كرسي

'Forma Solis secundum opinionem Picatricis est forma regis in cathedra sedentis et in eius capite coronam habentis, et formam corvi ante ipsum habentis et sub eius pedibus figuram Solis quam antediximus. Et hec est eius forma'. Magrịịi 1986, book 2, chap. 10, 66.

62 It was not unheard of for Campanella to use Arabic sources. In his critique of Scholastic science, its culture and practices, and the geocentric ancient universe, he set his eyes on Eastern cultures, which he saw as the bearers of an alternative scheme of science and politics, even latently guarding scriptural remnants of the ancient heliocentric cosmology. Noel Malcolm (2005) has argued that Campanella's interest in the Near East and the Ottomans went beyond the use of foreign sources, stressing the East as the site of a philosophy, a practice, and a politics that emerged by natural magic. Luigi Amabile's early reconstruction of the reasons for Campanella's imprisonment pointed out the connection between his political activity and his intellectual work in natural magic and in politics of apocalypse (see Amabile 1882, vol. 1, 226-28; vol. 3, doc. 7, 15-17). The details of the conspiracy of which Campanella was accused are striking. In June 1599, an Ottoman fleet commanded by Mūrat Reis was anchored near Reggio Calabria. Mūrat Reis was actually an Italian, originally Scipione Cicala, captured as a boy and recruited to the devshirme, the Ottoman institute for training captive boys as bureaucrats and soldiers. The now successful Mūrat Reis had stopped at Reggio Calabria merely to see his mother in Messina. But Campanella and his partners visited Mūrat Reis on his ship, urging him to invade Calabria so as to intensify the apocalyptic process, which, they hoped, would cause the pope to flee to a utopian retreat called La città del sole. For Malcolm, the conspiracy shows that Campanella adopted from the Ottomans the political institutions that he later presented in his scientific-political utopia. See Malcolm 2005, 41-67. On the conspiracy and its relation to Campanella's thought, see Ernst 2010, 67-85. 
sons in natural magic so that they could 'know how to rule according to the dogma of the world republic'.

\section{Conclusion}

For Renaissance thinkers unfriendly to the establishment, natural magic offered an alternative program for the philosophy of nature. Moreover, these rebels presented natural magic as a scientific practice, a culture deeply grounded in non-European contexts. For Ficino and Pico, natural magic originated in the ancient Near East and was brought to Renaissance Europe through cross-cultural exchanges that involved Kabalistic texts and Arabic works on magic. For Agrippa, natural magic carried a new program for science, as well as new practices and new personas. For him, the magus - the new experimental naturalist - was a figure that first came to life in the ancient East. For Campanella, natural magic offered a bottom-up construction of natural philosophy that also entailed a new organisation of society, in which reason and firsthand experience order both nature and society. In imagining this alternative, they eventually returned their science to its historical point of origin, the East. Ficino, Agrippa, and, in a sense, Campanella, pushed the argument further, laying a foundation for a heliocentric worldview, initiating the search for the hidden forces of nature, and casting the virtuoso magician as the godfather of natural philosophy.

The explicit and implicit presence of the Picatrix in the writing of these key figures indicates that the text played a central role in stirring discussions that aimed at turning natural magic into philosophy of nature, transforming the magus into an experimentalist, and converting the practice of natural magic into an institutional system of education.

\section{References}

Agrippa von Nettesheim, Heinrich Cornelius. 1575. De incertitudine et vanitate scientiarum declamatio invectiva, ex postrema authoris recognitione. Coloniae: Apud Theodorum Baumium.

Agrippa von Nettesheim, Heinrich Cornelius. 1992. Cornelius Agrippa. De occulta philosophia libri tres. ed. Vittoria Perrone Compagni. Studies in the history of Christian thought 48. Leiden: Brill.

Amabile, Luigi. 1882. Fra Tommaso Campanella, la sua congiura, i suoi processi e la sua pazzia: Narrazione con molti documenti inediti politici e guidiziarii, con l'intero processo di eresia e 67 poesie di fra Tommaso Finoggi ignorate. 3 vols. Napoli: Morano. 
Avilés, Alejandro García. 2011. 'La magie astrale comme art visuel au XIIle siècle’. In Boudet, Caiozzo and Weill-Parot (eds.). 95-123.

Ben-Zaken, Avner. 2011. Reading Hayy Ibn-Yaqzan: a cross-cultural history of autodidacticism. Baltimore, MD: Johns Hopkins University Press. 65-100.

Boudet, Jean-Patrice, Anna Caiozzo and Nicolas Weill-Parot. 2011. Images et magie: Picatrix entre Orient et Occident. Paris: Champion.

Campanella, Tommaso. 1623. De sensu rerum et magia libri quatuor. Paris.

Campanella, Tommaso. 1629. Astrologicorum libri VI: in qvibus astrologia, omni superstitione Arabum, et Judæorum eliminata, physiologice tractatur, secundum S. Scripturas et doctrinam S. Thomæ, et Alberti, et summorum Theologorum; ita ut absque suspicione mala in Ecclesia Dei multa cum utilitate legi possint. Frankfurt.

Campanella, Tommaso. 1631. Atheismus triumphatus seu Reductio ad religionem per scientiarum veritates. F. Thomae Campanellae ... contra antichristianismum achitophellisticum. Sexti tomi pars prima. Romae: Apud haeredem Bartholomaei Zannetti. Campanella, Tommaso. 1637. Thomas Campanella ... de sensu rerum, et magia, libros quatuor ... dedicat consecratque. Parisiis: Du Bray.

Campanella, Tommaso. 1638. Universalis philosophiae, seu metaphysicarum rerum, iuxta propria dogmata partes tres. Paris: Langlois.

Campanella, Tommaso. 1995. La città del sole. ed. Massimo Baldini. Roma: Newton Compton.

Callataÿ, Godefroid de. 2011. 'Sabéens de Harrân dans l'œuvre d'Yves Marquet'. In Boudet, Caiozzo and Weill-Parot (eds.). 41-56.

Copenhaver, Brian P. 1984. 'Scholastic philosophy and Renaissance magic in the "De vita" of Marsilio Ficino', Renaissance Quarterly 37.4. 523-54.

Copenhaver, Brian P. 2015. Magic in Western culture: from antiquity to the Enlightenment. Cambridge: Cambridge University Press.

Delcorno Branca, Daniela. 1976. 'Un discepolo del Poliziano: Michele Acciari’, Lettere italiane 28. 464-71.

Ernst, Germana. 2010. Tommaso Campanella: the book and the body of nature. Dordrecht: Springer.

Ficino, Marsilio. 1989. Three books on life (De vita libri tres). ed. and trans. Carol V. Kaske. Binghamton, NY: Renaissance Society of America.

Ficino, Marsilio. 2003. Platonic theology. ed. James Hankins, trans. Michael J. B. Allen and John Warden. Cambridge, MA: Harvard University Press.

Fierro Bello, María I. 1996. 'Batinism in al-Andalus: Maslama B. Qasim al-Qurtubi, d. 353-964, author of the "Rutbat al-hakim" and the "Ghayat al-hakim", Picatrix', Studia Islamica 84. 7-112.

Garin, Eugenio. 1983. Astrology in the Renaissance: the zodiac of life. London: Routledge and Kegan Paul.

Grafton, Anthony. 2004. 'A Note from inside the Teapot'. In Teaching New Histories of Philosophy, ed. Jerome B. Schneewind, Princeton, NJ: University Center for Human Values, Princeton University. 317-28.

Magrīțī, Maslama Ibn-Aḥmad al. 1986. Picatrix: the Latin version of the Ghāyat Al-Hakīm; text, introduction, appendices, indices. ed. David Pingree. Studies of the Warburg Institute 39. London: Warburg Institute.

Magrīțī, Maslama Ibn-Aḥmad al. 1933. K. Gājat al-ḥakīm wa-aḥaqq an-natīgatain bi't-taqdīm = Das Ziel des Weisen / Pseudo-Mağrīțī. ed. Hellmut Ritter. Leipzig: Teubner. 
Malcolm Noel. 2005. 'The Crescent and the City of the Sun: Islam and the Renaissance Utopia of Tommaso Campanella', Proceedings of the British Academy 125. 41-67.

Mirandola Pico, della. 1998. On the dignity of man; On being and the one; Heptaplus. trans. Charles G. Wallis, Indianapolis: Hackett.

Mirandola Pico, della. 1946. Disputationes adversus astrologiam divinatricem: libri I-V. ed. Eugenio Garin. Edizione nazionale dei classici del pensiero italiano 2. Firenze: Vallecchi.

Otto, B. (2016). Historicising 'Western Learned Magic'. Aries - Journal for the Study of Western Esotericism, 16(2), 161-240.

Perrone Compagni, Vittoria. 1975. 'Picatrix latinus', concezioni filosofico-religiose e prassi magica. Padova: Editrice Antenore.

Perrone Compagni, Vittoria. 1977. 'La magia cerimoniale del Picatrix nel Rinascimento’, Atti dell'Accademia di scienze morali e politiche di Napoli 88. 279-330.

Perrone Compagni, Vittoria. 2011. 'Picatrix: une philosophie pour la pratique'. In Boudet, Caiozzo and Weill-Parot (eds.). 359-73.

Pingree, David. 1981. 'Between the Ghaya and Picatrix I: the Spanish version', Journal of the Warburg and Courtauld Institutes 44. 27-36.

Saif, Liana. 2015. The Arabic influences on early modern occult philosophy. Basingstoke: Palgrave Macmillan.

Weill-Parot, Nicholas. 2011. 'Images corporeiformes et similitudo dans le Picatrix et dans le monde latin médiéval'. In Boudet, Caiozzo and idem (eds.). 117-35.

Yates, Frances A. 1964. Giordano Bruno and the Hermetic tradition. London: Routledge and Kegan Paul.

Zambelli, Paola. 2007. White Magic, Black Magic in the European Renaissance: From Ficino, Pico, Della Porta to Trithemius, Agrippa, Bruno. Leiden: Brill.

Ziegeler, Wolfgang. 1973. Möglichkeiten der Kritik am Hexen- und Zauberwesen im ausgehenden Mittelalter: zeitgenöss. Stimmen u. ihre soziale Zugehörigkeit. Köln: Böhlau. 
